\title{
Influence of a Mixture of Biosolar and Pertamax on Diesel Engine Power and Fuel Consumption
}

\author{
$1^{\text {st }}$ Poppy Puspitasari \\ Mechanical Engineering Department \\ Center of Nano Research and Advanced Materials, \\ Universitas Negeri Malang, \\ Indonesia \\ poppy@um.ac.id \\ $3^{\text {rd }}$ Agustian Yohan Effendi \\ Mechanical Engineering Department, \\ Universitas Negeri Malang, \\ Indonesia
}

\author{
$2^{\text {nd }}$ Paryono \\ Mechanical Engineering Department, \\ Universitas Negeri Malang, \\ Indonesia \\ Paryono.ft@um.ac.id \\ $4^{\text {th }}$ Marji \\ Mechanical Engineering Department, \\ Universitas Negeri Malang, \\ Indonesia \\ Marji.ft@um.ac.id \\ $5^{\text {th }}$ Johan Way an Dika \\ Postgraduate Program, \\ Universitas Negeri Malang, \\ Indonesia \\ johanwayandika@gmail.com
}

\begin{abstract}
The subject of fuel consumption and vehicle power is intrinsically interesting and worthy of study particularly in relation to the use of fuel mixtures. This study examined a mixture of $\mathbf{4 0}$ litres of Biosolar and 1 litre of Pertamax used to fuel a diesel engine. In this experimental study, the object being researched was an Isuzu Panther car with a $2230 \mathrm{cc}$, four-cylinder indirect injection diesel engine. The engine rotation varied from $1400 \mathrm{rpm}$ to $2900 \mathrm{rpm}$, with a margin of $300 \mathrm{rpm}$. The researchers used a dyno tester as a power metre and a measuring tube as a fuel consumption gauge. Data analysis was performed through paired samples t-tests with a significant level of 0.05 ; calculations were done with the aid of SPSS 22 for Windows. The research results indicated that there was a difference in power of the diesel engine using pure Biosolar; there was a difference in power of the diesel engine using a mixture of Biosolar and Pertamax; there was a difference in fuel consumption of using a mixture of Biosolar and Pertamax; there was a difference in engine power between the use of pure Biosolar and a mixture of Biosolar and Pertamax; there was a difference in fuel consumption between the use of pure Biosolar and a mixture of Biosolar and Pertamax.
\end{abstract}

\section{Keywords: Power, Fuel Consumption, Fuel Mixture}

\section{INTRODUCTION}

People's dependence on fuel oil is a severe problem [1]. Given the diminishing supply and increasing cost of fuel oil, many people are seeking alternatives to this energy source [2][3][4]. The type of fuel oil that is efficient and relatively inexpensive to maintain is diesel fuel [5]. One of the motor fuels that is efficient and relatively inexpensive to maintain is diesel [6]. Diesel is a motor fuel for an internal combustion engine using the heat of compression to cause ignition and bum fuel injected into the combustion chamber [7]. Unlike gasoline engines or gas engines, diesel engines do not use spark plugs [8].

There are several ways to improve fuel efficiency. However, not many people know that there is an easy method such as mixing a diesel fuel with Pertamax. Pertamax serves to accelerate the combustion in the combustion chamber, because it has a high thermal efficiency of $32 \%$ [9]. During fuel injection or combustion, Pertamax burns faster because the carbon chain in Pertamax is shorter than Biosolar. In this mixture, Pertamax occupies a role like a catalyst which in this case as a combustion accelerator. A ratio of 40:1 is applied to the mixture because Pertamax is only used for accelerating ignition due to its shorter carbon chain.

\section{METHODOLOGY}

This experimental research involved three types of variables. The independent variables included Biosolar and a mixture of Biosolar and Pertamax. The dependent variables were the engine power and fuel consumption produced by indirect injection diesel engines. The moderator variables included a vehicle engine after getting a tune-up. The engine rotation varied from $1400 \mathrm{rpm}$ to $2900 \mathrm{rpm}$, and the power measuring device and fuel consumption metre were in good condition. Biosolar and a mixture of Biosolar with Pertamax were used. At the time of data collection, the engine temperature was in working temperature.

The variables were developed into instruments for collecting data. The instruments were validated and consulted to experts before being used. Data analysis was done through paired t test with a 0.05 significance level because this study aimed to test two paired samples having a distinct or distinct mean [10]. Before the statistical tests performed, then first 
perform the normality test (normality test) in order to see the population is normally distributed. Calculations were performed with the help of SPSS 22 for Windows [11].

The object being researched was an Isuzu Panther car with a 2230cc, four-cylinder indirect injection diesel engine. The fuel used was Biosolar with a cetane number of 49 and Pertamax with an octane number of 92 . The data collection and analysis were carried out in the chemistry laboratory of Universitas Negeri Malang and the automotive laboratory of VEDC.

\section{RESULT AND DISCUSSION}

The data obtained were described to equate the interpretation of research results. The data presented were data from the experiment conducted on the C223 Isuzu diesel engine at VEDC, Malang. The data including the average power and fuel consumption were recorded at each engine rotation per treatment. The data collected were then inputted into tables to be analysed further.

\section{A. Data Analysis}

Data were analysed using a paired samples t-test. Here is shown graphs on fuel consumption and power, each shown in Figures 1 and 2.

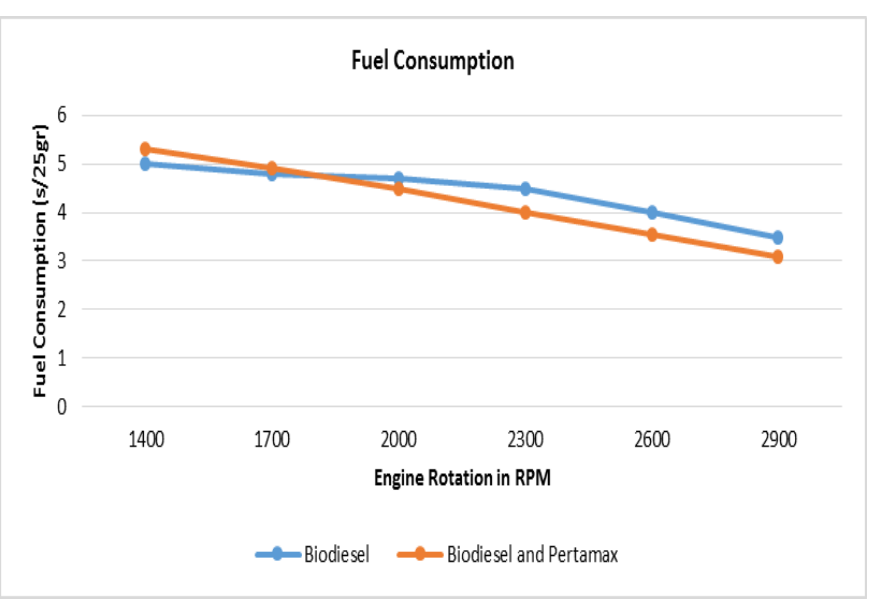

Fig.1. Fuel consumption of Biosolar and the mixture of Biosolar and pert amax with the increase RPM

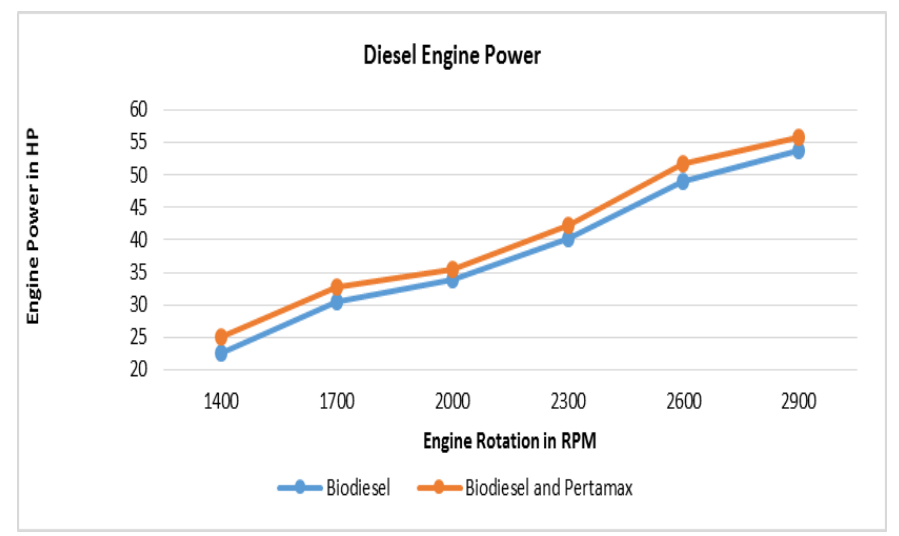

Fig. 2. Diesel engine power of Biosolar and the mixture of Biosolar and pertamax with the increase of RPM

\section{B. Normality Test using the Kolmogorov-Smirnov Test}

Decision making of the One Sample Kolmogorov Smirnov method is done by simply reading the significance value (Asymp Sig 2-tailed) [12]. A significance value of fewer than 0.05 means that a set of data is not normally distributed, while that of greater than 0.05 indicates a normally distributed data set. In this study, the results of normality test indicate that the data are normally distributed in each variation of treatment or fuel.

T ABLE I. NORMALITY TEST ON FUEL CONSUMPTION USING KOLMOGOROVSMIRNOVTEST

One-Sample Kolmogorov-Smirnov Test

\begin{tabular}{|c|c|c|}
\hline & & $\begin{array}{l}\text { Fuel } \\
\text { Consumption }\end{array}$ \\
\hline$\overline{\mathrm{N}}$ & & 12 \\
\hline \multirow[t]{2}{*}{ Normal Parameters ${ }^{\mathrm{a}, \mathrm{b}}$} & Mean & 4,3125 \\
\hline & Std. Deviation & ,70971 \\
\hline \multicolumn{2}{|c|}{ Most Extreme DifferencesAbsolute } & , 188 \\
\hline & $\overline{\text { Positive }}$ &, 124 \\
\hline & Negative &,- 188 \\
\hline Test Statistic & & , 188 \\
\hline Asymp. Sig. (2-tailed) & & $200^{\mathrm{c}, \mathrm{d}}$ \\
\hline \multicolumn{3}{|c|}{ a. Test distribution is Normal. } \\
\hline \multicolumn{3}{|l|}{ b. Calculated from data. } \\
\hline \multicolumn{3}{|c|}{ c. Lilliefors Significance Correction. } \\
\hline \multicolumn{3}{|c|}{$\mathrm{d}$. This is a lower bound of the true sign } \\
\hline
\end{tabular}

TABLE II. NORMALITY TEST ON ENGINE POWER USING KOLMOGOROVSMIRNOVTEST

One-Sample Kolmogorov-Smirnov Test

\begin{tabular}{lll}
\hline $\mathrm{N}$ & & Engine Power \\
\hline Normal Parameters & & 12 \\
\hline Most Extreme Differences & Mean & 39,408 \\
\cline { 2 - 3 } & Std. Deviation & 11,2140 \\
\cline { 2 - 3 } & Positive &, 137 \\
\cline { 2 - 3 } & Negative &, 136 \\
\hline Test Statistic &,- 137 \\
\hline Asymp. Sig. (2-tailed) &, 137 \\
\hline a. Test distribution is Normal. &, $200^{\text {c,d }}$ \\
b. Calculated from data. & \\
c. Lilliefors Significance Correction. \\
d. This is a lower bound of the true significance.
\end{tabular}

The data were normally distributed since the significance value of each treatment was $0.200(0.200>0.05)$ as shown in Table I and II, and each variation in fuel had the same significance value of 0.200 . The normally distributed data were then tested for homogeneity of variances. 


\section{Test for Homogeneity of Variances}

T ABLE III. HOMOGENEITY OF VARIANCES ON FUEL CONSUMPTION

\section{Test of Homogeneity of Variances}

Fuel Consumption

\begin{tabular}{|c|c|c|c|}
\hline Levene Statistic & df1 & df 2 & Sig. \\
\hline 1,520 & 1 & 10 & ,246 \\
\hline
\end{tabular}

T able III shows that the significance value ( $\mathrm{Sig})$ is 0.246 or greater than $0.05(0.246>0.05)$, indicating that the power generated from the engine using Biosolar and that using a mixture of Biosolar and Pertamax is homogeneous or no difference

T ABLE IV. HOMOGENEITY OF VARIANCES ON ENGINE POWER Test for Homogeneity of Variances

Power

\begin{tabular}{llll}
\hline Levene Statistic & df1 & df2 & Sig. \\
\hline, 000 & 1 & 10 & .988 \\
\hline
\end{tabular}

Table IV shows that the significance value (Sig) is 0.988 or greater than $0.05(0.988>0.05)$, indicating that the power generated from the engine using Biosolar and that using a mixture of Biosolar and Pertamax is homogeneous or no difference.

The based result on table III and table IV, this has supported the basic assumption and met the prerequisites for conducting a paired samples t-test.

\section{T-Test Related Samples}

Fuel Consumption

The proposed hypotheses were as follows:

- $\mathrm{H}_{0}$ is no difference to fuel consumption on pure biosolar usage by using a mixture of biosolar fuel with pertamax.

- $\mathrm{H}_{1}$ is that there is a difference to fuel consumption on pure biosolar usage by using a mixture of biosolar fuel with pertamax.

TABLE V. PAIRED SAMPLES STATISTICS ON FUEL CONSUMPTION

Paired Samples Statistics

\begin{tabular}{lrrrrrr}
\hline & & & \multicolumn{2}{c}{ Std. } & \multicolumn{2}{c}{ Std. Error } \\
& & Mean & N & Deviation & \multicolumn{1}{c}{ Mean } \\
\hline Pair 1 & Fuel Variations & 1,50 & 12 &, 522 &, 151 \\
\cline { 2 - 7 } & Fuel Consumption & 4,3125 & 12 &, 70971 &, 20488 \\
\hline
\end{tabular}

T ABLE VI. PAIRED SAMPLES CORRELATIONS ON FUEL CONSUMPTION

Paired Samples Correlations

\begin{tabular}{lcccc}
\hline & & $\mathrm{N}$ & Correlation & Sig. \\
\hline Pair 1 & Fuel Variations \& Fuel & 12 &,- 166 &, 607 \\
& Consumption & 12 & & \\
\hline
\end{tabular}

TABLE VII. PAIRED SAMPLES TEST ON FUEL CONSUMPTION

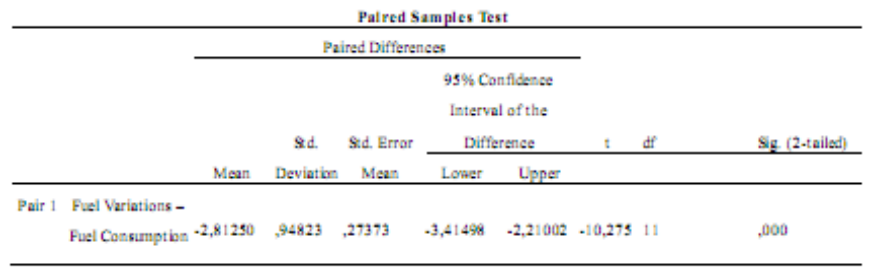

The value of $\mathrm{t}$ count $>\mathrm{t}$ table $(-10,275>2,201)$ and the significance of $0.05(0,000<0.05)$ then $\mathrm{H}_{0}$ is rejected, so it can be concluded that there is a difference in fuel consumption of diesel engines between using pure biodiesel with a mixture of biosolar fuel with pertamax. From the mean (average) can be seen if the average results of fuel consumption of diesel engines that use a mixture of biodiesel with pertamax more than that using pure biosolar. It can be concluded that by using a mixture of biodiesel fuel with pertamax, the diesel engine's fuel consumption is greater than using pure biosolar.

Diesel Engine Power

The proposed hypotheses were as follows:

- $\mathrm{H}_{0}$ is no difference to diesel engine power on pure biosolar usage by using a mixture of biosolar fuel with pertamax.

- $\mathrm{H}_{1}$ is that there is a difference to diesel engine power on pure biosolar usage by using a mixture of biosolar fuel with pertamax.

T ABLE VIII. PAIRED SAMPLES STATISTICS ON ENGINE POWER

Paired Samples Statistics

\begin{tabular}{|c|c|c|c|c|c|}
\hline & & Mean & $\mathrm{N}$ & Std. Deviation & Std. Error Mean \\
\hline \multirow[t]{2}{*}{ Pair 1} & $\begin{array}{c}\text { Fuel } \\
\text { Variation } \\
\end{array}$ & 1,50 & 12 &, 522 &, 151 \\
\hline & $\begin{array}{l}\text { Engine } \\
\text { Power }\end{array}$ & 39,408 & 12 & 11,2140 & 3,2372 \\
\hline
\end{tabular}

T ABLE IX. PAIRED SAMPLES CORRELATIONS ON ENGINE POWER

\begin{tabular}{|c|c|c|c|c|}
\hline \multicolumn{5}{|c|}{ Paired Samples Correlations } \\
\hline & & $\mathrm{N}$ & Correlation & Sig. \\
\hline Pair 1 & $\begin{array}{c}\text { Fuel Variation \& } \\
\text { Engine Power }\end{array}$ & 12 &, 102 & .753 \\
\hline
\end{tabular}

TABLE X. PAIRED SAMPLES TEST ON ENGINE POWER

\begin{tabular}{|c|c|c|c|c|c|c|c|c|}
\hline \multicolumn{9}{|c|}{ Pained Samples Test } \\
\hline & & \multicolumn{5}{|c|}{ Pared Differences } & 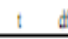 & If Sf (2.tailst) \\
\hline & & \multicolumn{7}{|c|}{$98 \%$ Conflibes Intevil of } \\
\hline & & \multirow[b]{2}{*}{ Man } & \multirow{2}{*}{$\begin{array}{c}\text { 8d } \\
\text { Deviation }\end{array}$} & \multirow{2}{*}{$\begin{array}{l}\text { Sd. Errar } \\
\text { Mezs }\end{array}$} & \multicolumn{2}{|c|}{ the Difference } & & \\
\hline & & & & & Lower & Lpper & & \\
\hline Pair 1 & Fual Variztion - Engine Power & $.91,9089$ & 11,1930 & 3,2254 & $.48,0073$ & $.30,8044$ &.$|1,793|$ &, 000 \\
\hline
\end{tabular}


Value $\mathrm{t}$ count $>\mathrm{t}$ table $(-11,753>2,201)$ and significance $0,05(0,000<0,05)$ then $\mathrm{H}_{0}$ is rejected, so it can be concluded that there is difference of power from diesel engine as above. From the mean (average) can be seen if the average power output of a diesel engine that uses a biosolar mixture with pertamax is greater than that using pure biosolar. It can be concluded that by using a mixture of biodiesel fuel with pertamax, the diesel engine's power is greater than using pure biosolar.

It can be concluded that by using a mixture of Biosolar and Pertamax, the power of a diesel engine is greater than using merely Biosolar. The higher the number of cetanes, the better the combustion. In addition to the properties of each fuel, i.e. having rapid combustion, the injection timing has an impact on the start of combustion [13].

The results also indicate that the higher the power of the vehicle engine, the more fuel is consumed. It is also influenced by increased engine speed due to the increased amount of air mixed into the fuel entering the combustion chamber. Also, faster rotation speeds on rear wheel cause more fuel consumption.

However, at low and medium engine speeds, the engine fuelled with a mixture of Biosolar and Pertamax consumed less fuel than that fuelled with Biosolar only. In fact, low rotation speeds result in less power. Fuel composition also affects fuel consumption, where the flashpoint in pure Biosolar is lower than that in a mixture of Biosolar and Pertamax. Also, a fast opening valve causes more air enters the combustion chamber, resulting in more fuel consumption. The injection timing complies with the standards of peak efficiency, the performance of a diesel motor is in medium loading only (electrical load of 15A), whereas when the loading is high, the engine consumes more fuel [13].

\section{CONCLUSION}

Taken together, the findings of this research on the power and fuel consumption of a diesel engine using Biosolar and that using a mixture of Biosolar and Pertamax (40:1) suggest the following conclusions.

- There is a difference to fuel consumption on pure biodolar use by using a mixture of biosolar fuel with pertamax
- In engine rotation in RPM 2000 - 2900, the consumption of biosolar mixed fuel with pertamax is greater than that of pure biosolar

- There is a difference to power on pure biosolar usage by using a mixture of biosolar fuel with pertamax

- The power generated by the use of biosolar mixtures with pertamax is greater than that of pure biosolar.

\section{REFERENCES}

[1] M. Tambunan, "The Second High Cycle of World Oil (Energy) Price Crisis: Challenges and Option. Global Dialogue on Natural Resources," Apr. 2006.

[2] BPHMIGAS, "National fuel consumption per year from 2006-2017,' Lower Oil and Gas Regulatory Agency (BPHMIGAS), 2017. [Online]. Available: http://www.bphmigas.go.id/konsumsi-bbm-nasional\# [Accessed: 15-Apr-2017].

[3] M. E. and M. Resources, Handbook of Energy and Economic Statistic of Indonesia. Center for Data and Information on Energy and Mineral Resources. Jakarta: Ministry Energy and Mineral Resources, 2009.

[4] P. Kuncahyo, A. Z. M. Fathallah, and Semin, "PREDICTION ANALYSIS OF BIODIESEL RAW MATERIAL POTENTIAL AS DIESEL MOT OR FUEL SUPPLEMENT S IN INDONESIA,” J. T ek. POMITS, vol. 2, 2013.

[5] J. S. Meliala, "OPTIMALIZATION EFFORT OF SAVINGS OF SUBSIDIES FUEL OIL (BBM) TO BE RIGHT TARGET," BINUS Bus. Rev., vol. 5, 2014.

[6] Pertamina, "Solar Oil Specification," 2006. [Online]. Available: http://www.pertamina.com. [Accessed: 15-Apr-2017].

[7] Arismunandar and Wiranto, Mover Motor Start Fuel Torak, 4th ed. Bandung: ITB, 1998.

[8] S. Mulyono, Gunawan, and B. Maryanti, "Influence of Fuel Efficiency Usage and Calculation Premium and Pertamax Against Gasoline Motor Fuel Performance,” J. Teknol. Terpadu, vol. 2, 2014.

[9] H. G, Know the Motor Burn. Makassar: Aneka Ilmu, 1987.

[10] S. Singgih, Mastering Parametric Statistics: Concepts and Applications with SPSS. Jakarta: PT. Elex Media Komputindo, 2015.

[11] A. B, Introduction to Social Statistics. Jawa Barat: Alfabeta, 2012.

[12] D. Priyatno, Easy and Fast Technique. Educational Analysis. Yogyakarta: Gava Media, 2010.

[13] S. Wardan, S. T. Budi, and W. Muhammad, "Characterization of Fuel In Diesel Motor," J. Saintek Res., vol. 20, 2015. 